\title{
Stakeholder participation in the formulation of Brazilian biofuel policy (RenovaBio)
}

\author{
Lira Luz Benites Lazaro \\ Lais Forti Thomaz
}

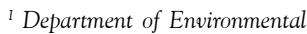
Health, School of Public Health, University of São Paulo, Av. Dr. Arnaldo, 715, 01246-904, São Paulo, Brazil.

"I University of Brasília (ELA/ UnB), Brasília, DF, and Federal University of Goiás, GO.

\begin{abstract}
In this article, we examine the establishment of the Brazilian biofuels policy (RenovaBio). We identify whether there was participation of stakeholders, and efforts of interest groups (associations, sugar refineries, and fuel distributors) to send technical notes and comments in order to have their perspectives heard and demands met, mainly regarding the definition of individual targets for reducing greenhouse gases (GHG). Government documents and stakeholder comments were consulted. For this purpose, we used the social network analysis technique. We argue that the capacity for social participation in these hearings can increase the influence of specific groups on political decisions. The results of the study show the predominant participation of trade associations and companies linked to the energy and biofuels sector. RenovaBio reaffirms the argument in favor of decarbonization, energy security, and the contribution of biofuels to reducing GHG, as motivating and legitimizing factors for their establishment.
\end{abstract}

Keywords: Governance; Energy Policy; Biofuel; RenovaBio; Social Network Analysis

São Paulo. Vol. 24, 2021

Special Issue: Energy territories

DOI: http://dx.doi.org/10.1590/1809-4422asoc20200056r2vu2021L4DE 


\section{Introduction}

Brazil has a long tradition of producing biofuels, mainly the production of sugarcane ethanol which has been promoted since 1931. At that time, Decree no 19717 established the ratio of $5 \%$ ethanol in gasoline (BRASIL, 1931). In 1975, the dictatorship government launched the National Alcohol Program (Proálcool) through Decree no 76,593, aiming to meet geopolitical and energy security objectives. The latter was a consequence of the international oil crisis and trade deficit caused by high oil prices and dependence on this foreign commodity. This boosted ethanol production given the need to increase the national trade balance and energy self-sufficiency. In 2003, the introduction of flexfuel cars resulted in significant increases in investments in ethanol production, further consolidation of the industry which led to the formation of large companies (BENITESLAZARO et al., 2017).

In 2004, the National Biofuels Program (PNPB) was launched, with the objective of increasing the production and use of biofuels in a sustainable manner, broadening family-based farming participation; stimulating Brazilian production from different oil plants, and also promoting the replacement of fossil diesel through a mandatory biodiesel mixture (CASTRO, 2011). The introduction of biodiesel in the Brazilian energy matrix was approved through Law 11,097 in 2005, which initially established the minimum mandatory percentage of $2 \%$ biodiesel in diesel oil sold to the final consumer. The percentage increased in the following years, reached 12\% in March 2020 (ANP, 2020), and is expected to reach 15\% according to Law No. 13,263 of 2016 (BRASIL, 2016).

Currently, the environmental benefits of biofuels are widely publicized among its supporters, recognizing in particular that ethanol has become, in the context of worldwide interest in renewable fuels, a way to reduce dependence on fossil fuels and greenhouse gas (GHG) emissions (BENITES-LAZARO et al., 2017). In the context of climate change, most countries understand that it is necessary to adopt ambitious policies and to substantially increase the production of low carbon energy to achieve both their climate goals and to ensure energy security in a more sustainable way (FLORINI; SOVACOOL, 2009; HUGHES; LIPSCY, 2013).

Brazil ratified the Paris Agreement in September 2016. As a result, it made a commitment to reduce GHG emissions by 37\% below 2005 levels, by 2025, and by 43\% in 2030 (MMA, 2015). In its Nationally Determined Contribution (NDC) submitted under the Paris Agreement, the country made two important commitments involving the energy sector: (1) reaching $45 \%$ of renewables in the energy matrix by 2030 - something that it would largely achieve by expanding the demand for renewable energy sources; and (2) increase the share of biofuels to approximately $18 \%$ by 2030 (UNFCCC, 2015). The expansion of consumption of biofuels can be achieved both by increasing ethanol production, including second generation biofuels; and by increasing the participation of the biodiesel mixture in diesel (UNFCCC, 2015).

Brazil's commitment under the United Nations Framework Convention on Climate Change (UNFCCC) and its recognition of the importance of sugarcane ethanol to achieve these objectives were celebrated by the sugar-energy companies. The sector 
demanded that the government adopt long-term policies to recognize the strategic role of biofuels in the energy matrix using the argument that ethanol is a means to achieve energy security, economic development, and mitigation of GHG emissions which come mainly from the transport sector (BENITES-LAZARO et al., 2020).

At the end of 2017, the Brazilian government approved its National Biofuels Policy, the so-called RenovaBio (Law 13,576). Its main objectives are: to achieve compliance with the goals agreed under the Paris Agreement; contribute to achieving energy efficiency and reducing GHG emissions; regulate the expansion, production and use of biofuels; contribute to the predictability of the competitiveness of the various biofuels in the national fuel market; and to make the supply of energy increasingly sustainable, competitive and safe. Mainly, RenovaBio presents an innovative approach to the creation and development of the carbon credits or decarbonization market (CBios) (BRASIL, 2017).

However, the fast approval in the National Congress, just 28 days, can bring into question the effectiveness of the civil society and private sector participation. Because, according to Marcelino (2020), when analyzing the proposals presented between 1990 and 2019 in the National Congress, the estimated average time for legislative approval was 1,279 days for PECs (Proposal for Amendment to the Constitution) and 1,263 days for Bills (PLs) and Project Complementary Law (PLPs).

In this article, we examine the establishment of the biofuels policy in Brazil (RenovaBio), identifying the main interest groups involved and their efforts to have their demands met in the process of formulating this policy. The sources used are government documents, and documents by the participating stakeholders (associations, sugar refineries, and fuel distributors) presented during public consultations and hearings, mainly in the definition of individual GHG reduction targets. The social network analysis methodology was used, which consists of the analysis of the social system expressed as standards and derived from the relationship between the entities that make up this system (WASSERMAN; FAUST, 1994).

From this, we intend to evaluate if, despite having been quickly approved in Congress, RenovaBio had significant participation of non-governmental actors in the process of the formulation of the program and its regulations. To this end, the text is divided into five sections in addition to this introduction. In the second part, we present a brief overview of the governance literature, climate regimes and stakeholder participation. In the third, we describe the methodology used in this study. In the fourth and fifth sections, aspects related to the conception and history of its formulation and its approval in the Federal Congress are presented. The participation of stakeholders in the public hearings for its regulation, specially related to the targets and to RenovaBio's goals is also analyzed. Finally, in the last section we present final remarks.

\section{Governance, climate regime and stakeholder participation}

Despite, climate change is closely associated with anthropogenic emissions of carbon dioxide (CO2) when two thirds of which come from energy production and use 
(IEA, 2015), however, the governance, the performance, and implementation of national energy policies has been limited (COLLAÇO et al., 2020). In addition, most of the existing studies that consider climate change mitigation as the main objective; understand that the energy sector is passively welcoming their consequences of these mitigation policies (TOKE; VEZIRGIANNIDOU, 2012; KOENGKAN; LOSEKANN; FUINHAS, 2019).

Several scholars have addressed energy governance, and have mainly emphasized an important issue "who governs energy" (FLORINI; SOVACOOL, 2009). The types of actors in this global energy governance have been mixed, including intergovernmental organizations, NGOs, multilateral financial institutions and hybrid entities, global political networks, public-private partnerships, transnational advocacy networks, private companies and quasi-regulatory bodies (SOVACOOL; FLORINI, 2012; VAN DE GRAAF; COLGAN, 2016). This has led some scholars to conceptualize this mosaic of institutions as a "regime complex" (RAUSTIALA; VICTOR, 2004; VAN DE GRAAF; COLGAN, 2016). 'Regime complex' has been defined as a global governance architecture, a set of partially overlapping institutions and non-hierarchical ones that govern in a given area of world politics (RAUSTIALA, VICTOR, 2004; BIERMANN et al., 2009; KEOHANE, VICTOR, 2011).

In recent years a 'regime complex' of energy entities has been trying to provide responses to global climate change (BERNSTEIN; HOFFMANN, 2018). In September 2015, the United Nations adopted a set of Sustainable Development Goals (SDGs), which include a specific energy target (SDG 7) which is "ensuring access to affordable, reliable, sustainable and modern energy for all" to be achieved by 2030 (UNITED NATIONS, 2015). Subsequently, during the 21st Conference of the Parties (COP-21) held in Paris in December 2015, more than 160 countries presented national plans on how they intended to contribute to the objectives of the post-2020 climate change convention (UNFCCC, 2015).

On the other hand, the regime complex for climate change, as established by Abbott (2012), could be understood using his proposal of a "governance triangle". This includes state organizations, companies and civil society, and provides a more comprehensive way to analyze this regime when states are the main actors. The author seeks to systematize governance, through transnational structures using three main categories found at the vertices of the triangle: (i) State, (ii) companies and (iii) civil society organizations. He points out that the greater the role played by actors of a specific type, the closer the scheme is located to the apex of that group of actors. Thus, the distance between each vertex and the opposite side of the triangle is a continuum, reflecting the level of involvement of the respective type of actor (ABBOTT, 2012). The Advocacy Coalition Framework (SABATIER, JENKINS-SMITH, 1988) defends the breaking of this iron triangle (Executive agencies, Legislative Commissions and Interest Groups), with the proposal to precisely involve more stakeholders, such as think tanks, academia and the media.

The emergence of regimes complex and the proliferation of plurality of actors in climate governance (ABBOTT, 2012) illustrate how governance increasingly occurs through a complex structure. This structure spans global and subnational levels, relies on formal 
and informal policy networks and channels (BULKELEY et al., 2014), and on a wider range of non-governmental organizations becoming active participants in governance. As Bevir (2011) points out, a distinctive feature of governance is the growing reach and plurality of stakeholders that are present in the policy-making process.

Although public participation is not a new fact, in recent decades, studies have shown an increase in "new governance" practices. These are designed in a more systematic way to increase the influence of stakeholders on policy, ensuring a broader representation in political decisions (FUNG, 2015). These recent governance trends have created opportunities for new previously marginalized stakeholders to participate more in solving public problems (BENITES-LAZARO; MELLO-THÉRY, 2019). Over the past 25 years or so, governments in various countries have sought to increase opportunities for public participation in decision-making. These efforts are related to the concept of political legitimacy and ideas of democracy (MCLAVERTY, 2011).

Previous studies show that there is no ideal solution among the legitimate demand for public participation, the need for technical and economic rationality, the need to make commitments, and the responsibility for the bad outcomes of the decision. Thus, several authors have proposed models that combine technical experts and rational decision making with public values and preferences (RENN, 1993; ROWE; GENE; FREWER, 2004; MARINAKIS et al., 2017). However, it turns out that the game of political relations internal to the State is not static. Political disputes take place in the statecraft paths of circulation of power internal to the state bureaucracy. These paths may not be democratically institutionalized, as only certain stakeholders end up having access to the political bargaining game that underlies the State's regulatory action (MATTOS, 2004).

\section{Methodology}

\subsection{Social network analysis}

The study of social networks analysis is largely interdisciplinary and has developed in many fields of human knowledge, including mathematics, physics, computation, biology and social sciences. A social network can be understood as a social structure composed of individuals or organizations, called nodes. These nodes can be collective (groups), such as teams, companies, cities, countries or entire species. These groups are connected by one or more specific types of interdependence, such as friendship, kinship, common interest, financial exchange, dislike, religion, sports team, values or beliefs. (WELLMAN; BERKOWITZ, 1988; BORGATTI et.al., 2013).

In social sciences, the notion that individuals are inserted in networks of relationships and social interactions has been emphasized. Social network theory provides an answer to a question that has preoccupied scholars since Plato's time, the problem of social order: how autonomous individuals can combine and agree to create lasting and functional societies (BORGATTI, et. Al, 2009). But it was only in the 1930s that network thinking specifically emerged as an approach, and provided a way to make the abstract social structure tangible. Jacob Moreno was a major contributor to investigations in the 
field of social relations and their network characteristics (SCOTT, 2011).

Until recently, the predominant approach in Social Network Analysis (SNA) has been the mathematical approach called "graph theory" (SCOTT, 2011). Graph theory originated in the mathematical investigations carried out by Leonhard Euler, and his wellknown problem with the seven Königsberg bridges is considered the first result of graph theory. In parallel with the work of graphs, there has been a matrix-based approach that does not focus on the properties of individuals and groups. This approach focuses on the characteristics of social positions, roles, and categories (SCOTT, 2011). These positional approaches - sometimes called "block models", are rigorous grouping matrix methods that organize networks in hierarchical positions (SCOTT, 2011).

Thus, the goal of SNA is to understand a community, mapping the relationships that connect them as a network and then trying to attract individuals, groups within the network ('components') and/or associations between individuals. A network is simply a number of points (or "nodes") connected by links - bridges or loops (BORGATTI; EVERETT; JOHNSON, 2013).

In this article we use the T-Lab software for the treatment of textual material and the construction of the adjacency matrix, and SonecTv for analysis and visualization of social networks. For a meaningful visualization of a social network, SocNetV has several algorithms and layout models. We use the degree centrality index (degree centrality) and Kamada-Kawai positioning algorithms (KAMADA; KAWAI, 1989). The measure centrality of the degree quantifies how many links a node has with other nodes in the network. In the ARS, this index is often considered a measure of the actor's activity. It can be calculated on non-targeted and targeted networks / relationships, but is generally more suitable for non-targeted networks (KALAMARAS, 2019).

\subsection{Data Analysis}

The documents analyzed were government documents (Law No. 13,576, which established the National Biofuels Policy - RenovaBio, and Decree No. 9.308), and the contributions sent by the different associations to the public consultations that were carried out by:

a) Ministry of Mines and Energy (MME). Public consultation No. 26 of 02/15/2017; Public consultation no46 of 05/04/2018; Public consultation No.70; Public consultation No. 94 of 06/05/2020 (MME, 2020).

b) National Agency of Petroleum, Natural Gas and Biofuels (ANP): Consultation No. 23 / 2019; Public consultation on 10/2018; Public consultation No 7/2019 (ANP, 2019).

\section{The formulation and processing of the RenovaBio Program in Brazil}

RenovaBio emerged from MME's Biofuels' Division proposal in 2016. As shown in Table 1, the first sign of the government's interest in guiding an initiative that met COP21's commitments, was the Workshop "RenovaBio - Biofuels 2030", in December 
2016. Subsequently, MME held a Public Consultation No. 26 to define RenovaBio parameters. Initially, the Program would be presented as a proposal for an "Executive Order" (Medida Provisória in Portuguese). On August 25, 2017, a RenovaBio Technical Note (White paper) published on the MME website was produced by some entities from MME, the Ministry of the Environment (MMA), the National Agency of Petroleum, Natural Gas and Biofuels (ANP), and the Brazilian Agricultural Research Corporation (Embrapa). In addition to such government representatives, RenovaBio's Technical Note also had support from the Brazilian National Energy Policy Council (CNPE). The Academia was represented by the National Institute of Science and Technology for Studies on the United States (INCT-INEU), São Paulo University / Luiz de Queiroz College of Agriculture, National Laboratory of Science and Technology of Bioethanol (formerly known as CTBE), and the Agroicone (MME, 2017).

The possibility of using an Executive Order to launch the program would have been strengthened with collaboration from external entities for formulation of its technical note. However, the decision was repeatedly postponed. Concerns about potential inflationary impact blocked its routing (PORTO, 2017). Because there was no real progress, deputy Evandro Gussi (Partido Verde/ Green Party-SP) led the initiative to introduce the RenovaBio program as a bill (PL 9086/2017) on November 14, 2017. On November 21 , urgent processing was requested. The vote took place on November 28, 2017. The bill was approved with three amendments and sent to the Senate (CÂMARA DOS DEPUTADOS, 2019) on November 30, 2017.

There was a new urgency processing requirement. On December 12, Senator Fernando Bezerra (MDB / PE) reported the bill and granted the understanding in the Plenary for approval without any amendments (SENADO, 2017). The RenovaBio Bill was approved in just 28 days of legislative processing. It established the Brazilian National Biofuels Policy - RenovaBio by the Law No. 13,576, of 26 December 2017, - which was regulated by Decree No. 9,308, published on March 15, 2018, and revoked by Decree No. 9888 of June 27, 2018

Table 1. RenovaBio Timeline (2016-2020)

\begin{tabular}{|l|l|l|}
\hline Publication date & Description & Goal \\
\hline December 13, 2016 & $\begin{array}{l}\text { Release of the Re- } \\
\text { novaBio proposal }\end{array}$ & It Creates a National Biofuels Policy \\
\hline $\begin{array}{l}\text { February 15 to Mar- } \\
\text { ch 20, } 2017\end{array}$ & $\begin{array}{l}\text { MME's Public } \\
\text { Consultation No. } \\
26\end{array}$ & $\begin{array}{l}\text { It included the definition of the objectives, } \\
\text { values and strategic guidelines of the RenovaBio } \\
\text { program. }\end{array}$ \\
\hline
\end{tabular}




\begin{tabular}{|c|c|c|}
\hline June 18, 2017 & $\begin{array}{l}\text { CNPE's Resolu- } \\
\text { tion No. } 15\end{array}$ & $\begin{array}{l}\text { It established guidelines for the development of } \\
\text { the market for fuels, oil derivatives and biofuels }\end{array}$ \\
\hline December 26, 2017 & Law No. 13,576 & $\begin{array}{l}\text { It created the National Biofuel Policy - Renova- } \\
\text { Bio }\end{array}$ \\
\hline March 15, 2018 & Decree No. 9,308 & $\begin{array}{l}\text { It stipulated the definition of mandatory annual } \\
\text { targets for reducing greenhouse gas emissions for } \\
\text { the sale of fuels }\end{array}$ \\
\hline March 22, 2018 & $\begin{array}{l}\text { MME's Ordinance } \\
\text { No. } 103\end{array}$ & $\begin{array}{l}\text { It established and defines the functioning of the } \\
\text { RenovaBio Committee }\end{array}$ \\
\hline May 04, 2018 & $\begin{array}{l}\text { MME's Public } \\
\text { Consultation No. } \\
46\end{array}$ & $\begin{array}{l}\text { It submitted to public consultation the descrip- } \\
\text { tion of the first cycle of decarbonization targets of } \\
\text { the RenovaBio Program }\end{array}$ \\
\hline May11 to 25,2018 & $\begin{array}{l}\text { ANP's Public } \\
\text { Consultation No. } \\
10\end{array}$ & $\begin{array}{l}\text { It publicized new regulations on the accreditation } \\
\text { of inspection firms aiming at the certification of } \\
\text { biofuels, according to Law No. } 13,576 \text {, regulated } \\
\text { by Decree No. } 9,308\end{array}$ \\
\hline June 05, 2018 & $\begin{array}{l}\text { CNPE's resolu- } \\
\text { tions No.5 }\end{array}$ & $\begin{array}{l}\text { It established the mandatory annual targets for } \\
\text { reducing greenhouse gas emissions }\end{array}$ \\
\hline August 2018 & $\begin{array}{l}\text { Ordinance No. } \\
303 \text { of } 2018\end{array}$ & It created the RenovaBio Technical Group \\
\hline November 23, 2018 & $\begin{array}{l}\text { ANP's Resolution } \\
\text { No. } 758\end{array}$ & $\begin{array}{l}\text { It regulates the certification of biofuel production } \\
\text { and imports and establishes the Inspection Firms }\end{array}$ \\
\hline January 2019 & & Accreditation of the first inspection firms \\
\hline
\end{tabular}




\begin{tabular}{|c|c|c|}
\hline $\begin{array}{l}\text { March } 07 \text { to April } \\
04,2019\end{array}$ & $\begin{array}{l}\text { Public Consulta- } \\
\text { tion ANP n } 7\end{array}$ & $\begin{array}{l}\text { Its purpose is to obtain subsidies and additional } \\
\text { information on the proposed ANP Resolutions } \\
\text { and provides for the individualization of the } \\
\text { annual mandatory targets for the reduction of } \\
\text { greenhouse gas emissions for the sale of fuels, } \\
\text { refers to art. } 7 \text { of Law No. } 13,576 \text {, of December } \\
26,2017\end{array}$ \\
\hline $\begin{array}{l}\text { April } 20 \text { to May 30, } \\
2019\end{array}$ & $\begin{array}{l}\text { MME's Public } \\
\text { Consultation No. } \\
70\end{array}$ & $\begin{array}{l}\text { It proposed National Targets for Decarbonization } \\
\text { of the Fuel Matrix - Cycle 2020-2029, submitted } \\
\text { to public consultation }\end{array}$ \\
\hline June 12, 2019 & $\begin{array}{l}\text { ANP's Resolution } \\
\text { N. } 791\end{array}$ & $\begin{array}{l}\text { It instituted technical aspects of individualized } \\
\text { annual goals }\end{array}$ \\
\hline June 24, 2019 & $\begin{array}{l}\text { CNPE's resolution } \\
\text { N. } 15 / 2019\end{array}$ & $\begin{array}{l}\text { It defined the mandatory annual targets for redu- } \\
\text { cing greenhouse gas emissions for the sale of fuels. }\end{array}$ \\
\hline June 27, 2019 & $\begin{array}{l}\text { Decree N. 9,888 } \\
\text { of } 2019\end{array}$ & $\begin{array}{l}\text { It established the definition of mandatory annual } \\
\text { targets for reducing greenhouse gas emissions } \\
\text { for the sale of fuels, as set out in Law No. } \\
13576 / 2017 \text { and established the National Biofuels } \\
\text { Policy Committee. }\end{array}$ \\
\hline July 26, 2019 & $\begin{array}{l}\text { ANP's dispatch N. } \\
585 \text { of } 2019\end{array}$ & $\begin{array}{l}\text { It defined the mandatory individual targets, to be } \\
\text { fulfilled by fuel distributors, to reduce greenhouse } \\
\text { gas emissions that would run until December 31, } \\
2019 \text {. }\end{array}$ \\
\hline August 8, 2019 & $\begin{array}{l}\text { Decree No. 9,964 } \\
\text { of } 2019\end{array}$ & $\begin{array}{l}\text { It attributed to ANP the authority to define } \\
\text { CBioS financial backing operations (amends } \\
\text { Decree no } 9.888 \text { / 2019). }\end{array}$ \\
\hline $\begin{array}{l}\text { October } 25 \text { to No- } \\
\text { vember } 11,2019\end{array}$ & $\begin{array}{l}\text { ANP's Public } \\
\text { Consultation No. } \\
23\end{array}$ & $\begin{array}{l}\text { It obtained subsidies and additional information } \\
\text { for the proposed draft resolution that establishes } \\
\text { the necessary procedures with financial backing } \\
\text { for issuing the Decarbonization Credits, referred } \\
\text { to in art. } 14 \text { of Law No. 13,576, of December 26, } \\
\text { 2017, and amends Resolution ANP No. 758, of } \\
\text { November 23, 2018. }\end{array}$ \\
\hline
\end{tabular}




\begin{tabular}{|l|l|l|}
\hline November 21, 2019 & $\begin{array}{l}\text { MME's Ordinance } \\
\text { No. 419 }\end{array}$ & It regulates the CBios market \\
\hline December 05, 2019 & $\begin{array}{l}\text { ANP's Resolution } \\
\text { No. 802 }\end{array}$ & $\begin{array}{l}\text { It establishes the procedures for issuing Decarbo- } \\
\text { nization Credits with financial backing }\end{array}$ \\
\hline June 05, 2020 & $\begin{array}{l}\text { MME's Public } \\
\text { Consultation No. } \\
94\end{array}$ & $\begin{array}{l}\text { It proposed a definition of mandatory annual } \\
\text { targets for reducing greenhouse gas emissions for } \\
\text { the sale of fuels and their tolerance range }\end{array}$ \\
\hline August 18, 2020 & $\begin{array}{l}\text { CNPE's Resolu- } \\
\text { tion No. } 8\end{array}$ & $\begin{array}{l}\text { It defines the mandatory annual targets for redu- } \\
\text { cing greenhouse gas emissions for the sale of fuels. }\end{array}$ \\
\hline
\end{tabular}

Source: Based on ANP (2019), MME (2020). Note: The Table summarizes the events and procedures adopted since the idea of RenovaBio until August 2020. This synthesis illustrates the speed of the decisionmaking process of this public policy, the short time in public consultations. It contains, in addition to legislation, ordinances, decrees and resolutions, important dates in the history and purpose of public consultations.

It is worth mentioning that biofuel plants/producers are voluntary participants inf the program. They can have their production put through the Certification of Efficient Production of Biofuels process, in which the Inspection Firm or responsible certifier, authorized by ANP, evaluates data about the production and import process of biomass and biofuels, taking into account energy efficiency, GHG emissions, and the life cycle analysis measured by RenovaCalc.

This "calculator" generates the carbon intensity of fuels (MATSUURA et al.,2018). This value is used to provide the Biofuel Efficiency Score. This process is the means to verify the credibility and reliability of the performance evaluation of the program, which is necessary for compliance with the NDCs adopted by Brazil to comply with the Paris Agreement (MMA, 2015). Based on this process, the Certificate of Efficient Production of Biofuels is issued. This document guarantees the validation, "cradle-to-gate," of the inputs and the production infrastructure all the way to the preparation of the final product including the agricultural phase and later the industrial and commercial phase (MME, 2017).

The decarbonization credit generated, called CBio, is being traded on the stock exchange (compliance) so that the obligated parties, that is, the distributors, can buy them to prove they have accomplished their individual goals within the Program (MME, 2017). It is worth mentioning that the CBios market is also open to non-obligated parties who can invest in this decarbonization market.

In the first half of 2020, due to the pandemic derived from COVID-19, MME 
called for a public consultation to review the targets. CNPE issued Resolution No. 8 of August 18, 2020, reducing the original target from 28.7 million to 14.53 million CBios to be purchased by distributors (BRASIL, 2020). Even the goals of the following years were reduced, as shown in Figure 1.

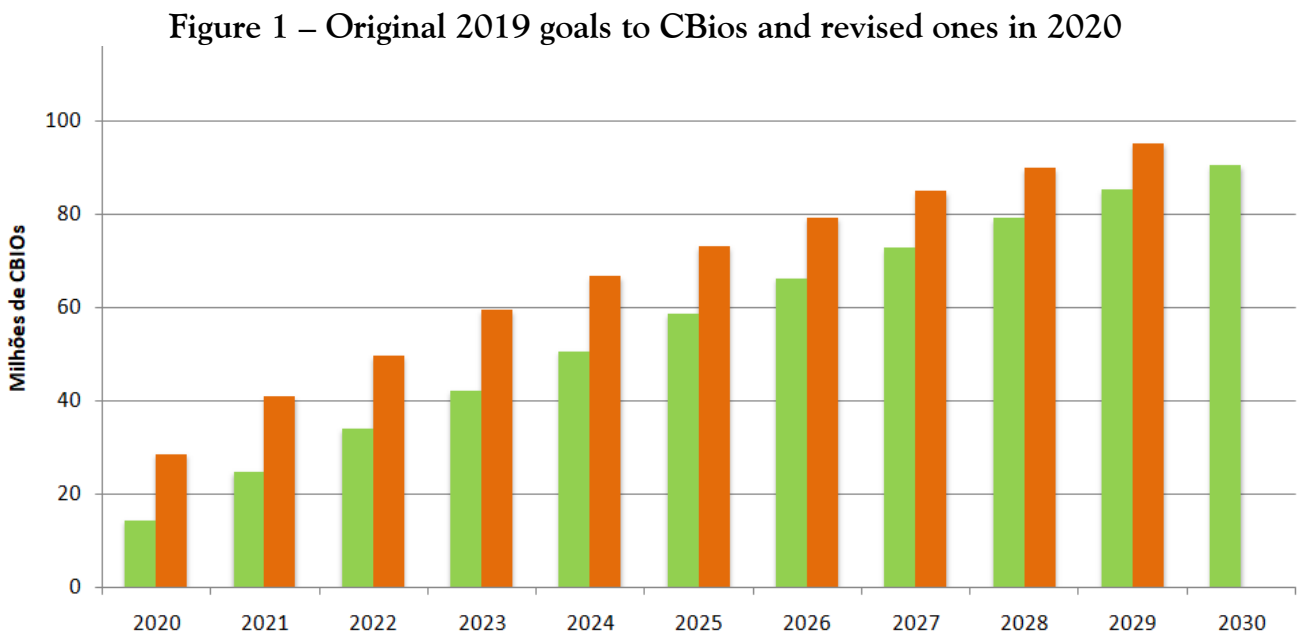

Source: Based on CNPE's Resolution No. 8/2020 and No. 15/2020 (BRASIL, 2019; BRASIL, 2020)

\section{Stakeholders role in the RenovaBio regulatory process}

RenovaBio became a law in December 2017, the regulatory process began after that. ANP and the National Energy Policy Council (CNPE) are responsible for regulating the Program together with MME. In addition to these bodies, the Biofuels and Fuels Monitoring Committee (CMBC) was created by the CNPE Resolution No. 15 and the RenovaBio Committee by Ordinance No. 103, of March 22, 2018 (MME, 2018). MME and ANP held Public Consultations and Hearings, as shown in Figures 2 and 3.

The first MME Public Consultation was number 26, on February 15, 2017, which addressed the objectives, values and strategic guidelines of the RenovaBio program. Stakeholders participated in consultation No. 26, as shown in Figure 2, including, for example: Brazilian Biodiesel and Biokerosene Union (UBRABIO), Brazilian Sugarcane Industry Association (UNICA), PETROBRAS, Association of Biofuel Producers in Brazil (APROBIO) and the Brazilian Institute of Oil, Gas and Biofuels (IBP). The second Public Consultation of MME was number 46, on May 4, 2018, in which the definition of the first cycle of decarbonization goals of the RenovaBio Program was discussed, as shown in Figure 2, with a greater participation of actors, mainly from the aviation sector. 
Figure 2. Stakeholders' participations in consultations and public hearings conducted by MME

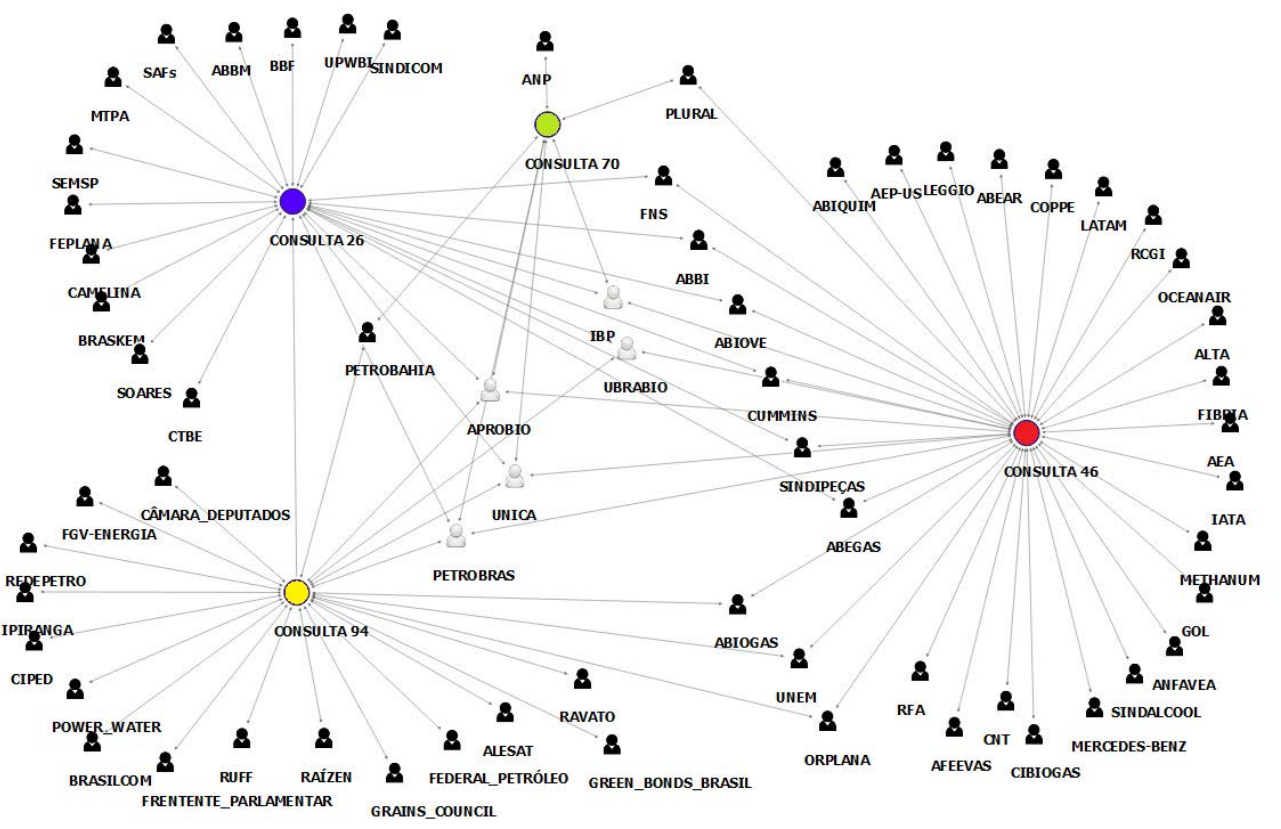

Source: Own illustration. Note: The degree centrality index used in the data analysis shows the centrality of actors who had greater participation at the events. Note, for example: Ubrabio, Abiove, FNS, etc, participated in two hearings and the predominance of four actors (PETROBRAS, UNICA, APROBIO, IBP) who participated in three hearings.

On the third Public Consultation No. 70, held on April 30, 2019, the theme was the proposal for maximum limits for the decarbonization targets of the fuel matrix, focusing on the 2020-2029 cycle - the initial period of validity of RenovaBio (MME, 2020). These emission reduction targets in the fuel matrix were defined, and published in Decree $\mathrm{N}$. 9,888 , on June 27,2019 , which has as main objective to induce the competitive, gradual and efficient reduction of carbon intensity in transportation fuel. It was determined that the ANP would be responsible for the goals distribution and for the publication of compliance or failure to comply by the distributor. The RenovaBio Committee and the CNPE would inspect and give recommendations on the projected values (BRASIL, 2019). The fourth MME's consultation held on June 94, 2020, was carried out in order to review the goals in light of the effects of the COVID-19 pandemic.

As shown in Figure 2, in consultations and public hearings conducted by MME, four relevant actors in the energy industry in Brazil, UBRABIO, UNICA, PETROBRAS, and IBP predominate. For example, UBRABIO - Uniao Brasileira do Biodiesel e Bioquerosene is an association that represents the entire production chain of biodiesel and biokerosene nationally. UNICA - Brazilian Sugarcane Industry Association is the largest representative organization of the sugar and ethanol sector in Brazil. The plants associ- 
ated with UNICA are responsible for more than $50 \%$ of the national production of sugar cane, $60 \%$ of the ethanol production and almost $70 \%$ of the bioelectricity offered to the National Interconnected System (SIN) (UNICA, 2019). PETROBRAS is one of the largest publicly held companies operating in an integrated and specialized manner in the oil, natural gas and energy industry.

It is also important to note that in addition to Brazilian associations, American ethanol industry associations such as the Renewable Fuels Association, Growth Energy and U.S. Grains Council submitted their contributions to public consultations. Another relevant point is the participation of airline companies such as Gol and Latam, which are major GHG emitters and contributed to issues related to aviation biokerosene.

Figure 3 shows the public consultations carried out by the ANP. Public consultation N. 10/2018 was held between May 11 and 25, 2018, followed by a hearing on May 29,2018 , to announce the new regulation on the accreditation of inspector firms, and consequently, the certification of biofuels. At the time of this consultation, the Law establishing RenovaBio was already in effect and Decree No. 9,308 was being discussed in this consultation and at the public hearing that took place on June 5, 2018 (ANP, 2019). On June 5, 2018, the CNPE set a target of $10.1 \%$ reduction in the intended carbon intensity (from $73.55 \mathrm{gCO} 2 / \mathrm{MJ}$ to $66.75 \mathrm{gCO} 2 / \mathrm{MJ}$ ) by the end of 2028. These projections numbers were 16.8 million CBios in 2019, which would progressively reach 91.1 million CBios in 2028, with tolerance intervals also established by the CNPE resolution.

Later, Resolution No. 758 was established on November 23, 2018, which specifies that the ANP, in addition to regulating the inspector firms, also regulates the criteria, procedures, concession, suspension and renewal of the Certificate of Efficient Production of Biofuels. Other provisions were established in relation to the voluntary participation of interested parties, and the biorefineries; that they are required to present all the information necessary for the calculation through RenovaCalc (ANP, 2019).

On March 7, 2019, the second ANP consultation No. 7/2019 dealt with the individualization of the compulsory annual targets set out in art. 7 of Law n. 3,576 of RenovaBio. Consultation n. 7 was available until April 4, 2019 and the Public Hearing took place on April 16. It should be noted that the possible penalties and formulas for measuring the market share of distributors were discussed there. After these procedures, through ANP Resolution n. 791 of June 12, 2019, technical aspects were established on the individualized annual targets, which will be generated from the multiplication of the distributor's market share in the total emissions from fossil fuels (percentage fraction) by the annual target established by CNPE (BRASIL, 2019).

The Public Consultation No. 23, the last one before the Program was implemented, took place from October 25th to November 11th, 2019 and its main objective was to determine the regulation that will guarantee the procedures for issuing the financial baking necessary for the emission of CBios. The issuing will only be possible through a digital platform called "CBio Platform". The public hearing took place on November 18,2019 , in order to discuss the draft approval of the criteria established through public consultation (ANP, 2019). 
Figure 3. Stakeholder participation in ANP's consultations and public hearings in the regulation of RenovaBio

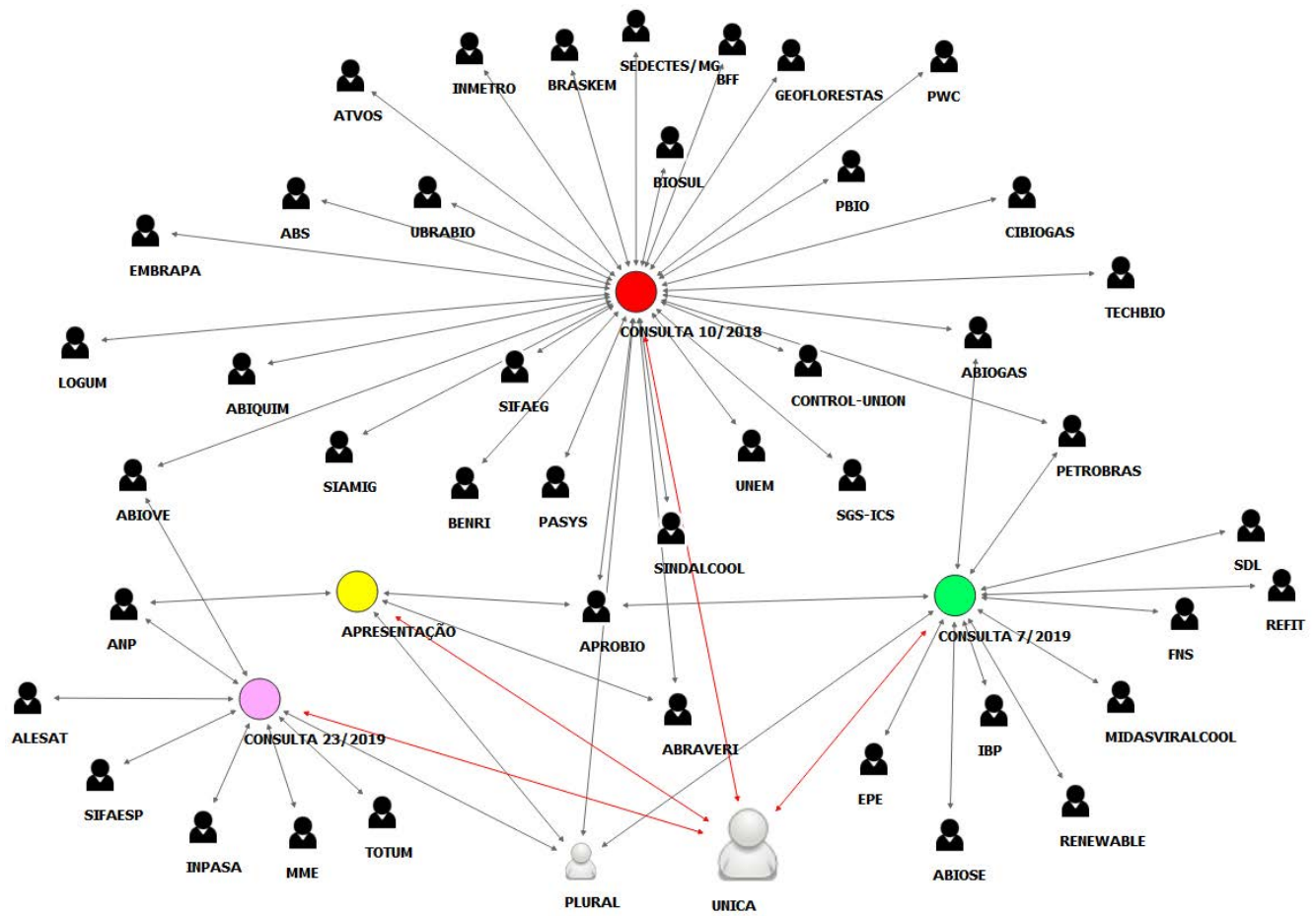

Source: Self illustration. Note: Presentation (in yellow) refers to presentations in ppt format sent to public hearing No. 23.

On December 20, the 135 distributors' individual targets had been published and they were considered obligated parties. Ipiranga took 19.87\%, Raízen acquired 17.89\% and Petrobrás seized $27.41 \%$, in accordance with the national distribution market share of the target established at the time. It was estimated that CBio would be traded at a value of 10 dollars.

Although these consultations and hearings received contributions from several organizations representing actors related to the biofuels sector, as shown in Figure 3, the centrality of two actors, UNICA and PLURAL, stands out. These two entities participated both with contributions in the consultations, and as presenters at the events. It is worth mentioning that PLURAL is a national trade organization that brings together the main fuel and lubricant distributors in the country, having among its associates: Air BP Brasil Ltda., Castrol Brasil Ltda., Cosan Lubrificantes e Especialidades SA, Chevron Brasil Lubrificantes Ltda., Ipiranga Produtos de Petróleo S.A., Petrobras Distribuidora SA, Petronas Lubrificantes Brasil SA, Raízen Combustíveis SA, Shell BrasilPetróleo Ltda., Total Lubrificantes do Brasil Ltda and YPF Brasil Comércio de Derivados de Petróleo Ltda. While UNICA, as mentioned above, is the entity that represents the main ethanolproducing units in the country. 
The study reveals, on the one hand, the direct involvement of parties seeking to influence planning and policy decisions in terms of their individual goals. The participation of biofuel producers, fossil producers and distributors as obligated parties is noted. These observations are in accordance with previous literature, which indicates that in many processes where there is primarily participation by stakeholders directly involved in the regulated industry, there may be limited political impact or the impact may favor those who participated to the detriment of the public interest (CROW; ALBRIGHT; KOEBALE, 2017; BALDWIN , 2019).

On the other hand, the study reveals the lack of participation by other stakeholders such as environmental NGOs or representatives of other sectors. even though the impact of the policies regarding production and use of bioenergy may occur in a context where water scarcity, soil degradation and food security are relevant issues. (BENITESLAZARO et al., 2020; BELLEZONI et al., 2018). For example, RenovaBio was under discussion when the Brazilian National Water Agency (ANA) issued its special report on irrigated sugarcane in 2017 (ANA, 2017), but this was not considered in the new policy. In addition, even though Renova Calc considers the elements of production and its first version included the Agroecological Zoning of sugarcane (ZAE cane), this zoning was revoked by Decree n. 10084, on November 19, 2019. Its requirements in Renova Calc were removed from the calculation.

Preliminary studies have shown that institutional design can influence which stakeholders participate, how they deliberate and share information and how stakeholders' engagement processes connect to political decisions (FUNG 2015; KOEBELE, 2017; BALDWIN, 2019). Even the institutional design and regulatory parts would have the capacity to reduce the undue influence of industrial stakeholders and increase the public interest stakeholders' influence (BALDWIN, 2019). However, the speed with which a law is passed raises concerns about the difficulty in increasing participation for other actors and civil society. It also raises questions about the opportunity for a broad debate by representatives of agents from the various sectors involved, as indicated by the results of this study.

Although, governance participatory approaches can increase legitimacy, social justice, and effectiveness of the decision-making processes. (CROW; ALBRIGHT; KOEBELE, 2017; BALDWIN, 2019), the final result can only be legitimate if it derives from a broad debate of the proposals with the participation of representatives of the actors from the various sectors involved. Previous studies have shown that decision makers often see stakeholder participation as a mere formality, or as a way of seeking legitimacy for their projects and programs, and not as a significant attempt to incorporate stakeholder concerns into political decisions (BALDWIN, 2019; BENITES-LAZARO; MELLO-THÉRY, 2019; BOUCHARD, 2016).

In recent years, most of the participation mechanisms introduced have been of a consultative nature (MCLAVERTY, 2011). In Brazil in particular, for 20 years, public consultation has been an instrument of popular participation provided by Brazilian legislation to support public activities in general. It has potential to contribute to the 
quality of administrative authority (MONTEIRO, 2018). According to the MME itself, public consultations are an instrument of the government to bring society closer to the normative routine, with regard to the public interest and decision-making process. One of its main objectives is to create a direct channel of communication with the population. With that, they can express themselves about the theme. Although the consultations are not mandatory because the opinions expressed will not necessarily be answered, hey demonstrate an effort by the government to observe more closely the clamors and suggestions of those who have any interest in the agenda.

Previous studies such as Aamodt (2018) and Santos (2020) show how in the Brazilian political system, interest groups often manage to obtain elected representatives for political and administrative positions. In this context, these groups would guarantee access and channels of influence to formal policy makers, facilitating the legitimization of their specific demands and interests. In the RenovaBio case, there is an example of the "revolving-door", in which the political decision maker finishes his legislative term and goes directly to an interest group position. This is the case of the Former Deputy Evandro Gussi (RenovaBio bill sponsor), who became UNICA's President. UNICA was clearly one of the entities that was a central participant in the policy development activities, as shown in Figures 2 and 3. For the sugarcane industry represented by UNICA, RenovaBio represents an opportunity to revitalize growth in the face of the crisis that affected it in the last decade.

On the other hand, it is understood that NGOs, especially international ones, defend the environment, advocate for the reduction of deforestation, and oppose the expansion of the agricultural frontier in areas considered sensitive. However, as previous studies show, these NGOs have their positions aligned with the sugar-energy sector because they "recognise" the virtues of Brazilian sugarcane ethanol for reducing GHG emissions (BENITES-LAZARO, et al, 2017). WWF, for example, has actively engaged with the industry using certification processes to promote sustainable production and use of sugarcane ethanol. In this respect, it is important to emphasize the role of BONSUCRO, a non-profit organization, which was created with the objective of specifically certifying the production of sugarcane (BONSUCRO, 2020).

The results of the study also reveal that the dominance of the private sector in public consultation processes in Brazil should be further studied, since some organizations may abstain from participating in public consultations and hearings due to a lack of confidence in such processes, which are predominantly technical. (SANTOS, 2020) or for other reasons. A genuine deliberation supported by participatory processes with multiple stakeholders and sectors would help to resolve potential bias when only a few stakeholders predominate. It would bring competing and interdependent themes to the agenda. Academia could also have had a greater participation in the consultations, although many researchers in the area were directly involved in its formulation, according to the consultants' composition in the Technical Note and the RenovaCalc white paper.

The public consultation processes, although they can be considered advances compared to the traditional clientelist and authoritarian practices of the Brazilian bu- 
reaucracy, contributes in a very restricted way to social and political empowerment, or to the power relations transformation (FREY, 2009). As Frey (2009) describes, the forms of participation effectively aim to transform the logic of the predominant power. Thus, it would be important to observe the scale or degree of social participation, as there is a big difference between strategies in the development of current policies, which advocate or require consultation processes, or even information for the population. However, they leave it up to the decision-making to the point where they want to consider such contributions or not and to the extent the opinions of "others" are consistent with their opinions, aspirations and needs.

\section{Final considerations}

The results of this study illustrate that the development of RenovaBio's national policy had as legitimizing arguments the need for policies in favor of decarbonization and against climate change, with the contribution of biofuels in reducing GHG beneficial to fulfilling commitments assumed under the Paris Agreement. However, the results also show the lack of engagement of several stakeholders in the process. The non-participation of representatives from other sectors, entities linked to environmental NGOs opposed to biofuels or even in defense of the end of fossils was observed in the public consultations and hearings analyzed, as shown in Figures 2 and 3.

This issue is important as several studies are showing the relevance of governance based on the dynamics of a wide range of sectors and stakeholders, specifically to show the trade-offs and interdependencies with sectors in land and water use beyond biofuels. This discussion could include how sustainable use of resources can be achieved. In addition, we emphasize the lack of more significant action by groups defending the implementation of the Paris Agreement, even from academia, the participation of these groups could have guaranteed, for example, a smaller reduction in the revised goals (Figure 1), remaining at levels closer to the original program goals.

The results of this study show a dominant concern with economic factors because, RenovaBio, in addition to its environmental and energy security arguments, brings many investment expectations related to a new product in the biofuels market, CBios which are negotiable on the stock exchange. CBios is an inspiring pilot project for all other production chains. It could even be a Brazilian example in the implementation of Article 6 of the Paris Agreement, in relation to the carbon market.

In short, this article sought to meet a critical need for research on stakeholder involvement in energy policy decisions and energy governance. Understanding which national policies are effective in reducing emissions from the energy sector becomes especially important, as is studying the participation of actors in the establishment and regulation of these policies. Thus, future studies may be aimed at researching how to more effectively incorporate the contribution of stakeholders in energy policy decisions. 


\section{Acknowledgments}

Lira Luz Benites Lazaro acknowledge the financial support received from São Paulo Research Foundation (FAPESP) Process: 2017/17796-3, Process n ${ }^{\circ}$ 19/24479-0, and Process n ${ }^{\circ}$ 15/03804-9. Laís Forti Thomaz thanks the financial support by the Distrito Federal Foundation (SEI-GDF No. 798/2019 - FAPDF/ SUCTI/COOTEC). We appreciate the collaboration of Beatriz Almeida and Joanne Ivancic to improve our manuscript.

\section{References}

ABBOTT, Kenneth W. The transnational regime complex for climate change. Environment and Planning C: Government and Policy, v. 30, n. 4, p. 571-590, 2012.

AAMODT, Solveig. The ability to influence: A comparative analysis of the role of advocacy coalitions in Brazilian climate politics. Review of Policy Research, v. 35, n. 3, p. 372-397, 2018.

ANA - Agência Nacional de Águas - Atlas irrigação de cana-de-açúcar. 2017.

ANP - Agência Nacional de Petróleo, Gás Natural e Bicombustíveis. RenovaBio. Disponível em: http://www.anp.gov.br/producao-de-biocombustiveis/RenovaBio. Acesso em 31 dezembro 2019.

.Abastecimento de biodiesel. 2020. Disponível em: http://www.anp.gov.br/n oticias/5808-abastecimento-de-biodiesel. Acesso em 28 de ago 2020.

BALDWIN, Elizabeth. Exploring how institutional arrangements shape stakeholder influence on policy decisions: A comparative analysis in the energy sector. Public Administration Review, v. 79, n. 2, p. 246-255, 2019.

BELLEZONI, Rodrigo A. et al. Water-energy-food nexus of sugarcane ethanol production in the state of Goiás, Brazil: An analysis with regional input-output matrix. Biomass and Bioenergy, v. 115, p. 108-119, 2018.

BENITES-LAZARO, L. L. et al. Land-water-food nexus of biofuels: Discourse and policy debates in Brazil. Environmental Development, p. 100491, 2020.

BENITES-LAZARO, L. L.; MELLO-THÉRY, N. A. Empowering communities? Local stakeholders' participation in the clean development mechanism in Latin America. World Development, v. 114, p. 254-266, 2019.

BENITES-LAZARO, L.L.; MELLO-THÉRY, N.A. SIMÕES, A.F.; GNACCARINI, I. Governança e desenvolvimento sustentável: a participação dos stakeholders locais nos projetos de Mecanismos de Desenvolvimento Limpo no Brasil. Cuadernos de Geografía: Revista Colombiana de Geografía, v.27.2, p. 227-241, 2018.

BENITES-LAZARO, L. L.; MELLO-THÉRY, N. A.; LAHSEN, M. Business storytelling about 
energy and climate change: The case of Brazil's ethanol industry. Energy research $\&$ social science, v. 31, p. 77-85, 2017.

BERNSTEIN, Steven; HOFFMANN, Matthew. The politics of decarbonization and the catalytic impact of subnational climate experiments. Policy Sciences, v. 51, n. 2, p. 189-211, 2018.

BONSUCRO. World Wide Fund for Nature. Disponível em: https://www.bonsucro.com/members/world-wide-fund-for-nature/. Acesso em 27 ago 2020.

BORGATTI, Stephen P. et al. Network analysis in the social sciences. science, v. 323, n. 5916, p. 892-895, 2009.

BORGATTI, Stephen P.; EVERETT, Martin G.; JOHNSON, Jeffrey C. Analyzing social networks. Sage, 2018.

BOUCHARD, Nancy. The dark side of public participation: Participative processes that legitimize elected officials' values. Canadian Public Administration, v. 59, n. 4, p. 516-537, 2016.

BRASIL. Decreto no19.717, de 20 de fevereiro de 1931.

.Lei n⿳0 13.263 de 2016, dispõe sobre os percentuais de adição de biodiesel ao óleo diesel comercializado no território nacional. Disponível em: http://www.planalto.gov.br/ccivil_03/_ ato2015-2018/2016/lei/L13263.htm. Acesso em 11 set 2020.

.Lei $n^{\circ} 13.576$, de 26 de dezembro de 2017. Dispõe sobre a Política Nacional de Biocombustíveis. Disponível em: http://www.planalto.gov.br/ccivil_03/_Ato2015-2018/2017/Lei/ L13576.htm. Acesso em 05 set 2019.

.Decreto $n^{\circ} 9.888$, de 27 de junho de 2019. Dispõe sobre a definição das metas compulsórias anuais de redução de emissões de gases causadores do efeito estufa para a comercialização de combustíveis. Disponível em: https://legis.senado.leg.br/norma/31158192/publicacao/31158205. Acesso em 10 set 2019.

. Despacho Resolução n8, de 18 ago. 2020. Disponível em: https://www.in.gov.br/en/web/

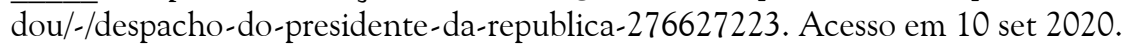

BULKELEY, Harriet et al. Transnational climate change governance. Cambridge University Press, 2014.

CÂMARA DOS DEPUTADOS. Tramitação PL 9086/2017. Disponível em: https://www.camara.leg.br/proposicoesWeb/fichadetramitacao?idProposicao=2162285. Acesso em 08 nov 2019.

CASTRO, César Nunes. O programa nacional de produção e uso do biodiesel (PNPB) e a produção de matéria-prima de óleo vegetal no norte e no nordeste. IPEA, Texto para Discussão 1613, 2011.

COLGAN, Jeff D.; KEOHANE, Robert O.; VAN DE GRAAF, Thijs. Punctuated equilibrium in the energy regime complex. The Review of International Organizations, v. 7, n. 2, p. 117-143, 
2012.

COLLAÇO, Flávia Mendes de Almeida et al. Understanding the Energy System of the Paulista Macrometropolis: first step in local action toward climate change. Ambiente $\&$ Sociedade, v. 23, 2020.

CONGRESSO NACIONAL. Veto n 49/2017. Disponível em: https://www.congressonacional. leg.br/materias/vetos/-/veto/detalhe/11603. Acessoem 13 ago 2019.

CROW, Deserai A.; ALBRIGHT, Elizabeth A.; KOEBELE, Elizabeth. Evaluating informational inputs in rulemaking processes: A cross-case analysis. Administration $\mathbb{E}$ Society, v. 49, n. 9, p. $1318-1345,2017$.

FLORINI, Ann; SOVACOOL, Benjamin K. Who governs energy? The challenges facing global energy governance. Energy Policy, v. 37, n. 12, p. 5239-5248, 2009.

FREY, Klaus. Governo inclusivo e serviços públicos de informação. Revista Brasileira de Biblioteconomia e Documentação, v. 5, n. 1/2, p. 84-103, 2009.

FUNG, Archon. Putting the public back into governance: The challenges of citizen participation and its future. Public Administration Review, v. 75, n. 4, p. 513-522, 2015.

HUGHES, Llewelyn; LIPSCY, Phillip Y. The politics of energy. Annual Review of Political Science, v. 16, 2013.

KALAMARAS, D.V. SocNetV. Social Network Visualizer, 2019.Disponívelem:https://socnetv. org/docs/index.html. Acesso em 10 ago 2019.

KAMADA, Tomihisa et al. An algorithm for drawing general undirected graphs. Information processing letters, v. 31, n. 1, p. 7-15, 1989.

KEOHANE, Robert O.; VICTOR, David G. The regime complex for climate change. Perspectives on politics, p. 7-23, 2011.

KOENGKAN, Matheus; LOSEKANN, Luciano Dias; FUINHAS, José Alberto. The relationship between economic growth, consumption of energy, and environmental degradation: renewed evidence from Andean community nations. Environment Systems and Decisions, v. 39, n. 1, p. 95-107, 2019.

MARCELINO, D. Congresso: tempo de tramitação cai de mais de mil dias para apenas 15 dias. Disponível em: https://www.jota.info/legislativo/congresso-tramitacao-aprovometro-25052020. Acesso em 22 jan 2021.

MATTOS, Paulo Todescan Lessa. Regulação econômica e social e participação pública no Brasil. In: Apresentado no IX Congresso Internacional do CLAD sobre a Reforma do Estado e a Administração Pública (Painel 116: Mecanismos de participação cidadã social na reforma do Estado no Brasil), Madri. 2004. 
MATSUURA, MISF. et al. Nota Explicativa da RenovaCalc. Disponível em: http://www.anp.gov. br/images/Consultas_publicas/2018/n10/CP10-2018_Nota-Tecnica-Renova-Calc.pdf. Acesso em 8 mar 2019.

MCLAVERTY P. Participation. In: BEVIR, Mark (Ed.). The SAGE handbook of governance. Sage, 2011.

MMA. Ministério Meio Ambiente (BR) (2015). Acordo de Paris - iNDC brasileira. Disponível em: https://www.mma.gov.br/clima/convencao-das-nacoes-unidas/acordo-de-paris. Acesso em 25 abr 2019.

MME. Ministério de Minas e Energia. Nota Explicativa do RenovaBio, 2017. Disponível em: http://www.mme.gov.br/documents/10584/135676503/Nota + Explicativa + RENOVABIO +-+Documento + de +CONSOLIDACAO+-+ site.pdf/2bc724d5-ae20-4da8-a401-ecaed45f6alf. Acesso em 08 mar 2019.

.Portaria n⿳0 103, de 22 de março de 2018. Disponível em:http://www.in.gov.br/materia/-/ asset_publisher/Kujrw0TZC2Mb/content/id/7876862/do1-2018-03-26-portaria-n-103-de-22de-marco-de-2018-7876858. Acesso em 29 abr 2019.

. Consulta Públicas -RenovaBio. 2020. Disponível em: http://www.mme.gov.br/web/guest/ servicos/consultas-publicas. Acesso em 16 set 2020.

MONTEIRO, Vera. Art. 29 da LINDB-Regime jurídico da consulta pública. Revista de Direito Administrativo, p. 225-242, 2018.

PORTO, G. Proposta do RenovaBio deve tramitarem regime de urgência, diz Unica. Agencia Estado. 16 nov 2017. Disponível em: https://www.novacana.com/n/etanol/politica/proposta-RenovaBio-tramitar-regime-urgencia-unica-161117. Acessoem01 out 2019.

RAUSTIALA, Kal; VICTOR, David G. The regime complex for plant genetic resources. International organization, p. 277-309, 2004.

RENN, Ortwin et al. Public participation in decision making: A three-step procedure. Policy sciences, v. 26, n. 3, p. 189-214, 1993.

ROWE, Gene; FREWER, Lynn J. Evaluating public-participation exercises: a research agenda. Science, technology, \& human values, v. 29, n. 4, p. 512-556, 2004.

SABATIER, Paul A. An advocacy coalition framework of policy change and the role of policyoriented learning therein. Policy sciences, v. 21, n. 2-3, p. 129-168, 1988.

SANTOS, Inaiê Takaes. Confronting governance challenges of the resource nexus through reflexivity: A cross-case comparison of biofuels policies in Germany and Brazil. Energy Research \&Social Science, v. 65, p. 101464, 2020.

SCOTT, John. Social network analysis: developments, advances, and prospects. Social network analysis and mining, v. 1, n. 1, p. 21-26, 2011. 
SENADO FEDERAL. Projeto de Lei da Câmara n 160, de 2017. Disponível em: https://www25. senado.leg.br/web/atividade/materias/-/materia/131765. Acesso em 08 nov 2019.

SOVACOOL, Benjamin K.; FLORINI, Ann. Examining the complications of global energy governance. Journal of Energy \& Natural Resources Law, v. 30, n. 3, p. 235-263, 2012.

TOKE, David; VEZIRGIANNIDOU, Sevasti-Eleni. The relationship between climate change and energy security: key issues and conclusions. Environmental Politics, v. 22, n. 4, p. 537-552, 2013.

UNICA - União da Indústria de Cana-de-Açúcar. Histórico e missão. Disponível em https:// unica.com.br/sobre-a-unica/historico-e-missao/. Acesso em 28 dez 2019.

UNFCCC - United Nations Framework Convention on Climate Change. 2015. The Paris Agreement and NDCs. Disponível em: https://unfccc.int/process-and-meetings/the-paris-agreement/ nationally-determined-contributions-ndcs.Acessoem 08 fev 2020.

VAN DE GRAAF, Thijs; COLGAN, Jeff. Global energy governance: a review and research agenda. Palgrave Communications, v. 2, n. 1, p. 1-12, 2016.

WASSERMAN, Stanley et al. Social network analysis: Methods and applications. Cambridge university press, 1994.

WELLMAN, Barry; BERKOWITZ, Stephen D. Social structures: A network approach. CUP Archive, 1988. 
Lira Luz Benites Lazaro

凹lbenites@usp.br

ORCiD: https://orcid.org/0000-0001-6587-1497
Submitted on: 15/04/2020

Accepted on: 02/05/2021

2021;24e:00562

\section{Laís Forti Thomaz}

$\varangle$ laisthomaz@ufg.br

ORCiD: https://orcid.org/0000-0002-3488-1462

How to cite: LAZARO, L.L.B; THOMAZ, L.F. Stakeholder participation in the formulation of Brazilian biofuels policy (RenovaBio). Ambiente $\&$ Sociedade. São Paulo, v. 24, p. 1-23, 2021. 


\title{
A Participação de stakeholders na formulação da política brasileira de biocombustíveis (RenovaBio)
}

\author{
Lira Luz Benites Lazaro \\ Lais Forti Thomaz
}

São Paulo. Vol. 24, 2021

Dossiê especial:

Territórios da Energia
Resumo: Neste artigo, examinamos o estabelecimento da Política dos Biocombustíveis (RenovaBio). Identificamos se houve participação dos stakeholders, e os esforços dos grupos de interesse (associações, usinas, e distribuidoras de combustíveis) no envio de notas técnicas e comentários para terem suas demandas atendidas, principalmente na definição das metas individuais de redução de gases de efeito estufa (GEE). Os documentos governamentais e das entidades de representação foram consultados. Para este propósito, utilizamos a técnica social network analysis. Discutimos que a capacidade de participação social nas audiências pode aumentar a influência de grupos específicos sobre as decisões políticas. Os resultados do estudo mostram a participação predominante de associações e empresas mais ligadas ao setor da energia e dos biocombustíveis. O RenovaBio reafirma o argumento em prol da descarbonização, a segurança energética, e a contribuição dos biocombustíveis na redução de GEE, como fatores motivadores e legitimadoras para seu estabelecimento.

Palavras-chave: Governança; Política Energética; Biocombustivéis; RenovaBio; Social Network Analysis

Como citar: A Participação de stakeholders na formulação da política brasileira de biocombustíveis (RenovaBio). . Ambiente $\&$ Sociedade. São Paulo, v. 24, p. 1-24, 2021. 


\title{
La participación de los stakeholders en la formulación de la política brasileña de biocombustibles (RenovaBio)
}

\author{
Lira Luz Benites Lazaro \\ Laís Forti Thomaz
}

São Paulo. Vol. 24, 2021

Dossier especial:

Territórios de Energía
Resumen: En este artículo, examinamos el establecimiento de la política brasileña de Biocombustibles (RenovaBio). Identificamos si hubo participación de los stakeholders, y el esfuerzo de los grupos de interés (asociaciones y distribuidores de combustibles) en el envío de notas técnicas y comentarios para satisfacer sus demandas, principalmente en la definición de metas individuales de reducción de gases de efecto invernadero (GEI). Se consultaron documentos gubernamentales y de entidades representativas. Utilizamos la técnica de análisis de redes sociales. Argumentamos que la capacidad de participación social en estas audiencias puede incrementar la influencia de grupos específicos en las decisiones políticas. Los resultados del estudio muestran la participación predominante de asociaciones y empresas más vinculadas al sector de la energía y los biocombustibles. RenovaBio reafirma el argumento a favor de la descarbonización, la seguridad energética y el aporte de los biocombustibles en la reducción de GEI, como motivador y discurso legitimador para su establecimiento.

Palabras-clave: Gobernanza; Política Energética, Biocombustibles; Renovabio; Análisis de redes sociales.

Como citar: Gobernanza; Política Energética, Biocombustibles; Renovabio; Análisis de redes sociales. Ambiente $\&$ Sociedade. São Paulo, v. 24, p. 1-22, 2021. 